\title{
Single-particle Characterization of Aerosol Particles Collected Nearby a Lead Smelter in China
}

\author{
Hae-Jin Jung, Young-Chul Song, Xiande Liu' ${ }^{1)}$, Yuwu $\mathrm{Li}^{2}$ and Chul-Un Ro* \\ Department of Chemistry, Inha University, 253, Yonghyun-dong, Nam-gu, Incheon 402-751, Korea \\ ${ }^{1)}$ Chinese Research Academy of Environmental Sciences, Beijing, 100012, China \\ ${ }^{2)}$ National Research Center for Environmental Analysis and Measurements, Beijing, 100029, China
}

*Corresponding author. Tel: +82-32-876-7106, E-mail: curo@inha.ac.kr

\begin{abstract}
China has been a top producer and exporter of refined lead products in the world since the year 2000. After the phasing-out of leaded gasoline in the late 1990s, non-ferrous metallurgy and coal combustion have been identified as potential major sources of aerosol lead in China. This paper presents the single particle analytical results of ambient aerosol particles collected near a lead smelter using a scanning electron microscopy-energy dispersive $x$-ray spectroscopy (SEMEDX). Aerosol particle samples were collected over a 24-hour period, starting from 8 pm on 31 May 2002, using a high volume TSP sampler. For this near source sample, 73 particles among 377 particles analyzed (accounting for 19.4\%) were lead-containing particles mixed with other species $(\mathrm{S}, \mathrm{Cl}, \mathrm{K}, \mathrm{Ca}$, and/or $\mathrm{C})$, which probably appeared to be from a nearby lead smelter. Lead-containing particles of less than $2 \mu \mathrm{m}$ size in the near source sample were most frequently encountered with the relative abundances of $42 \%$. SEM-EDX analysis of individual standard particles, such as $\mathrm{PbO}, \mathrm{PbS}, \mathrm{PbSO}_{4}, \mathrm{PbCl}_{2}$, and $\mathrm{PbCO}_{3}$, was also performed to assist in the clear identification of lead-containing aerosol particles. Lead-containing particles were frequently associated with arsenic and zinc, indicating that the smelter had emitted those species during the non-ferrous metallurgical process. The frequently encountered particles following the lead-containing particles were mineral dust particles, such as aluminosilicates (denoted as $\mathrm{AlSi}$ ), $\mathrm{SiO}_{2}$, and $\mathrm{CaCO}_{3}$. Nitrate- and sulfate-containing particles were encountered frequently in 2-4 $\mu \mathrm{m}$ size range, and existed mostly in the forms of $\mathrm{Ca}\left(\mathrm{NO}_{3}, \mathrm{SO}_{4}\right) / \mathrm{C},(\mathrm{Mg}$, $\mathrm{Ca}) \mathrm{SO}_{4} / \mathrm{C}$, and $\mathrm{AlSi}+\left(\mathrm{NO}_{3}, \mathrm{SO}_{4}\right)$. Particles containing metals (e.g., $\mathrm{Fe}, \mathrm{Cu}$, and $\mathrm{As}$ ) in this near source sample had relative abundances of approximately $10 \%$. Although the airborne particles collected near the lead smelter contained elevated levels of lead, other types of particles, such as $\mathrm{CaCO}_{3}$-containing, carbonaceous, metal-containing, nitrates, sulfates, and fly-ash par-
\end{abstract}

ticles, showed the unique signatures of samples influenced by emissions from the lead smelter.

Key words: Lead-containing particle, Low- $Z$ particle EPMA, Single particle analysis, Lead smelter

\section{INTRODUCTION}

The main sources of airborne lead particles in the atmosphere can be divided into anthropogenic and natural sources. The reported anthropogenic sources include vehicle exhaust, coal combustion, metallurgic industry, cement industry, etc (Zhang et al., 2009; Tan et al., 2006; Wang et al., 2000). The lead particles from these sources appeared predominantly in the fine fraction (Zhang et al., 2009; Murphy et al., 2007; Sun et al., 2006; Tan et al., 2006; Wang et al., 2006). Fine particles can penetrate easily and be absorbed in the blood vessels of human lungs because of their small size and large surface area, respectively, possibly leading to a range of diseases (Nemmar et al., 2010; Löndahl et al., 2007; Donaldson et al., 2001; Oberdorster, 2001; Schwartz, 2001; Seaton et al., 1995). Lead can adversely affect the health of humans, particularly children, even at trace levels (Bowers and Beck, 2006; Papanikolaou et al., 2005; Hilary, 2001; Winneke et al., 1990; Fulton et al., 1987; Yule et al., 1981). Therefore, considerable effort has been made to reduce airborne lead particles around the world. The use of leaded gasoline has been banned in the United States and Europe since 1975 and mid-1980s, respectively, to control airborne lead particles from vehicle emission, which is one of the major sources of airborne lead particles (Zhang et al., 2009). China, the top producer and exporter of refined lead products in the world since 2000 (http:// www.ila-lead.org), has also banned the use of leaded gasoline in big cities, such as Beijing, Shanghai, and Guangzhou, since 1997. In Guangzhou, Wuhan, Lanzhou, and Chongqing, the lead concentrations in $\mathrm{PM}_{2.5}$ were reported to range from 476.4 to $635.9 \mathrm{ng} / \mathrm{m}^{3}$ in 
1995 and 1996, which was before the phase-out of leaded gasoline (Hu and $\mathrm{Wu}, 1999)$. High levels of airborne lead, however, have still been reported in China. In 1999 and 2000, after the phase-out of leaded gasoline, the lead level was still high, more than $300 \mathrm{ng} / \mathrm{m}^{3}$ in Beijing (He et al., 2001). The mean $\mathrm{Pb}$ concentrations were also reported to be $100-300 \mathrm{ng} / \mathrm{m}^{3}$ during 2000 and 2004 in Beijing (Sun et al., 2006). These studies suggest that the lead level still remained high due to the presence of other sources, even though lead emission from vehicles has been reduced, which was pointed out in other studies (Widory et al., 2010; Xiao et al., 2008; Wang et al., 2006).

Currently, the highest levels of lead in particulate matter (PM) is normally found near lead smelters (http:// www.epa.gov/oar/lead), and lead refining smelters have been identified as one of the three major sources for airborne lead particles, along with aviation gasoline use and coal combustion in United States (Murphy et al., 2007). In Jiyuan, Henan province, China, there are more than 30 lead refining smelters, one of which is the largest lead producer in Asia. These companies have produced lead for more than 50 years. Lead particles from these smelters might be responsible for the high level of airborne lead, resulting in an adverse health effect. For example, it was reported that the blood lead concentrations in approximately one third of children examined in 2009, who lived near lead smelters at Henan province, exceeded the lead poisoning standard $(100 \mu \mathrm{g} / \mathrm{L})$ according to the World Health Organization, with symptoms of lead poisoning (http://news.sina.com. $\mathrm{cn} / \mathrm{c} / 2009-10-16 / 022518838893 . s h t m l)$. Airborne lead from lead smelters can be transported to other regions by the wind, possibly affecting people in wide range of areas. So it is imperative to elucidate the characteristics of aerosol particles near the smelter to determine the characteristics of aerosols emitted from a lead smelter. Bulk analysis, which provides only average composition of the particulate samples, may not be proper for the analysis of this type of samples because lead-containing particles are usually on trace level in the atmosphere. In this study, an airborne sample collected near the lead smelter was analyzed using a single particle analysis technique, named low- $Z$ particle electron probe $X$-ray microanalysis (low- $Z$ particle EPMA). Low- $Z$ particle EPMA was also performed for individual standard particles, such as $\mathrm{PbO}, \mathrm{PbS}$, $\mathrm{PbSO}_{4}, \mathrm{PbCl}_{2}$, and $\mathrm{PbCO}_{3}$, to help identify the leadcontaining aerosol particles.

\section{EXPERIMENTAL}

\section{1 Samples}

The aerosol sample was collected near a lead smelter located in Jiyuan, Henan province, China, which is one of the largest lead producers in Asia, over a 24-hour period starting from $8 \mathrm{pm}$ on May 31, 2002, using a high volume TSP sampler. The population of Jiyuan is approximately 682,500 over $1,931 \mathrm{~km}^{2}$ area, and there are more than 30 lead smelters. Sampling was carried out on the roof of a building, which was approximately 500 meters away from the smelter. During the sampling, the wind direction was from the smelter to the sampling place although the wind was not strong $(\sim 3-4 \mathrm{~m} / \mathrm{s})$. The sample is an ambient TSP sample in nature but appeared to have a high lead content. Therefore, it can be used as a near source sample. Hereafter, the particle sample collected near the lead smelter was designated a "near source sample". For single particle investigation using low- $Z$ particle EPMA, aerosol particles were transferred on Ag foil (0.025 mm thickness, $99.95 \%$, Goodfellow). Ag foil was simply rubbed over the surface of the sample collected by TSP sampler. Some particles adhering to the Ag foil by the electrostatic nature of the adhesive forces were analyzed.

Low- $Z$ particle EPMA analysis was also carried out for individual standard particles, such as $\mathrm{PbO}$ (Aldrich, PN 211907, $\geq 99.9 \%$ ), PbS (Aldrich, PN 372595, 99.9\%), $\mathrm{PbSO}_{4}$ (Aldrich, $\mathrm{PN} 307734,98 \%$ ), $\mathrm{PbCl}_{2}$ (Aldrich, $\mathrm{PN} 268690,98 \%$ ), and $\mathrm{PbCO}_{3}$ (Aldrich, $\mathrm{PN}$ $336378, \geq 99.98$ ), to help identify the lead-containing aerosol particles. For single-particle investigation, micrometer sized standard particles were collected on Ag foil. Sampling was done in the same way as for the near source sample particles.

\section{2 Low-Z Particle EPMA Single Particle Analysis}

The elemental analyses were carried out using the JEOL JSM-6390 scanning electron microscope equipped with an Oxford Link SATW ultrathin window EDX detector with a resolution of $133 \mathrm{eV}$ for $\mathrm{Mn}-\mathrm{K} \alpha \mathrm{X}$-rays. The X-ray spectra were recorded under the control of INCA Oxford software (Oxford Instruments Analytical Ltd, INCA suite version 4.09). A $20 \mathrm{kV}$ accelerating voltage and a beam current of $0.5 \mathrm{nA}$ were used for all measurements. A typical measuring time of $15 \mathrm{~s}$ was used to obtain sufficient counts in the X-ray spectra while limiting the beam damage effects on sensitive particles. A more detailed discussion on the measurement conditions was reported elsewhere (Ro et al., 1999). X-ray data acquisition for individual particles was carried out manually in point analysis mode, where the electron beam was focused at the center of each particle. The X-rays were acquired while the beam remained fixed on this single spot. Overall, 377 particles for the near source sample were analyzed.

The net X-ray intensities for the elements were 
obtained using a non-linear least-squares fitting of the collected spectra using the AXIL program (Vekemans et al., 1994). The elemental concentrations of the individual particles were determined from their X-ray intensities using a Monte Carlo calculation combined with reverse successive approximations (Ro et al., 2003, 2001). The quantification procedure provided accurate results within the $12 \%$ relative deviations between the calculated and nominal elemental concentrations when the method was applied to a range of standard particles, such as $\mathrm{NaCl}, \mathrm{Al}_{2} \mathrm{O}_{3}, \mathrm{CaSO}_{4} \cdot 2 \mathrm{H}_{2} \mathrm{O}, \mathrm{Fe}_{2} \mathrm{O}_{3}$, $\mathrm{CaCO}_{3}$, and $\mathrm{KNO}_{3}$ (Ro et al., 2004, 2003, 2000). Low$Z$ particle EPMA can provide quantitative information on the chemical composition, and particles can be classified based on their chemical species.

\section{RESULTS AND DISCUSSION}

\section{1 Lead-containing Standard Particles}

Individual standard particles of $\mathrm{PbO}, \mathrm{PbS}, \mathrm{PbSO}_{4}$, $\mathrm{PbCl}_{2}$, and $\mathrm{PbCO}_{3}$ were investigated by low- $Z$ particle EPMA to assist in the clear identification of lead-containing particles. In particular, differentiation of the $\mathrm{Pb} \mathrm{M}$ X-ray and S K X-ray lines was a major concern because their respective energies (2.342 and $2.307 \mathrm{keV}$, respectively) were too close to distinguish using an EDX detector. In addition, airborne lead particles can exist as a variety of sulfur-containing species, such as $\mathrm{PbSO}_{4}, \mathrm{PbS} \mathrm{PbSO}_{4} \cdot \mathrm{PbO}$, etc (Choël et al., 2006; Tan et al., 2006; Batonneau et al., 2004; Sobanska et al., 1999). On the other hand, the accurate curve fitting of the AXIL program for the $\mathrm{Pb} \mathrm{M}$-line and $\mathrm{S} \mathrm{K}$-line Xray peaks could be performed based on the different peak shapes of $\mathrm{Pb} \mathrm{M}$ and $\mathrm{S} \mathrm{K} \mathrm{X-rays.}$

For each standard powder sample, 20-25 particles were analyzed. Table 1 lists the mean diameter and elemental concentrations of the standard particles. The sizes of analyzed particles ranged from 0.97 to 11.97 $\mu \mathrm{m}$, where particles are mostly in the $2-6 \mu \mathrm{m}$ size range. As shown in Table 1, the atomic concentrations of the standard particles are close to their stoichiometries, i.e. $[\mathrm{Pb}]:[\mathrm{O}]=1: 1.34$ for $\mathrm{PbO},[\mathrm{Pb}]:[\mathrm{C}]:[\mathrm{O}]=1: 1.29$ : 3.40 for $\mathrm{PbCO}_{3},[\mathrm{~Pb}]:[\mathrm{S}]=1: 1.07$ for $\mathrm{PbS},[\mathrm{Pb}]:[\mathrm{S}]$ : $[\mathrm{O}]=1: 0.93: 3.92$ for $\mathrm{PbSO}_{4}$, and $[\mathrm{Pb}]:[\mathrm{Cl}]=1: 2.30$ for $\mathrm{PbCl}_{2}$. For the $\mathrm{PbCl}_{2}$ standard particles, the atomic concentration of chlorine was higher than their stoichiometry because overlap of the Ag L X-ray line of the collecting substrate with $\mathrm{Cl} \mathrm{K} \mathrm{X}$-ray line resulted in an inaccurate estimation of the $\mathrm{Cl} \mathrm{K}$-line intensity. Good results for $\mathrm{PbS}$ and $\mathrm{PbSO}_{4}$ standard particles clearly demonstrate that an accurate resolution of the $\mathrm{Pb}$ M-line and S K-line X-ray peaks had been achieved. On the other hand, all $\mathrm{Pb}$-containing standard particles contained significant amounts of carbon, particularly $\mathrm{PbO}$ and $\mathrm{PbCl}_{2}$, which had carbon contents of 16.6 and 20.1 at.\%, respectively. This appears to result from the carbonation at the particle surface by $\mathrm{CO}_{2}$ in the air and/or the absorption of carbonaceous species. Surface oxidation also appears to be significant for $\mathrm{PbO}$ and $\mathrm{PbS}$, which had oxygen contents of 49.7 and $47.3 \%$, respectively. Those carbon and oxygen species were probably entrained on the active surface of the particles when they were exposed to air and/or were ground using a mortar and pestle. Based on an analysis of standard $\mathrm{Pb}$-containing particles, it is clear that the $\mathrm{Pb}$ M-line and S K-line X-ray peaks can be resolved by applying a non-linear least-squares fitting using the AXIL program, and significant levels of surface carbonation and oxidation will make the speciation of $\mathrm{Pb}$-containing aerosol particles somewhat difficult.

\section{2 Near Source Sample}

Fig. 1 shows typical secondary electron images (SEIs)

Table 1. Elemental atomic concentrations and average diameters of standard lead-containing particles.

\begin{tabular}{|c|c|c|c|c|c|c|}
\hline \multirow{3}{*}{$\begin{array}{l}\text { Particle type } \\
\mathrm{PbO} \text { (Aldrich, } \\
\mathrm{PN} 211907, \geq 99.9 \% \text { ) }\end{array}$} & \multirow{3}{*}{$\begin{array}{c}\begin{array}{c}\text { Number of } \\
\text { particles analyzed }\end{array} \\
20\end{array}$} & \multicolumn{4}{|c|}{$\begin{array}{l}\text { Average elemental concentration } \\
\text { (at. \%) }\end{array}$} & \multirow{3}{*}{$\begin{array}{c}\begin{array}{c}\text { Average } \\
\text { diameter }(\mu \mathrm{m})\end{array} \\
4.05\end{array}$} \\
\hline & & $\mathrm{Pb}$ & $\mathrm{O}$ & $\mathrm{C}$ & & \\
\hline & & $37.0 \pm 6.0$ & $49.7 \pm 5.3$ & $16.6 \pm 4.8$ & & \\
\hline \multirow{2}{*}{$\begin{array}{l}\mathrm{PbCO}_{3} \text { (Aldrich, } \\
\mathrm{PN} \mathrm{336378,} \mathrm{99.98 \% )}\end{array}$} & \multirow{2}{*}{20} & $\mathrm{~Pb}$ & $\mathrm{O}$ & $\mathrm{C}$ & & \multirow{2}{*}{2.62} \\
\hline & & $17.6 \pm 3.6$ & $59.8 \pm 4.5$ & $22.6 \pm 2.7$ & & \\
\hline \multirow{2}{*}{$\begin{array}{l}\text { PbS (Aldrich, } \\
\text { PN 372595, 99.9\%) }\end{array}$} & \multirow{2}{*}{25} & $\mathrm{~Pb}$ & S & $\mathrm{O}$ & $\mathrm{C}$ & \multirow{2}{*}{3.75} \\
\hline & & $23.4 \pm 5.3$ & $25.1 \pm 7.0$ & $47.3 \pm 14.6$ & $5.9 \pm 4.5$ & \\
\hline \multirow{2}{*}{ 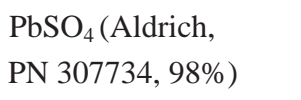 } & \multirow{2}{*}{25} & $\mathrm{~Pb}$ & $\mathrm{~S}$ & $\mathrm{O}$ & $\mathrm{C}$ & \multirow{2}{*}{2.06} \\
\hline & & $16.5 \pm 2.3$ & $15.4 \pm 3.3$ & $64.6 \pm 4.8$ & $4.6 \pm 3.3$ & \\
\hline \multirow{2}{*}{$\begin{array}{l}\mathrm{PbCl}_{2} \text { (Aldrich, } \\
\mathrm{PN} 268690,98 \% \text { ) }\end{array}$} & \multirow{2}{*}{20} & $\mathrm{~Pb}$ & $\mathrm{Cl}$ & $\mathrm{C}$ & & \multirow{2}{*}{6.24} \\
\hline & & $25.1 \pm 3.7$ & $57.8 \pm 6.3$ & $20.1 \pm 5.2$ & & \\
\hline
\end{tabular}



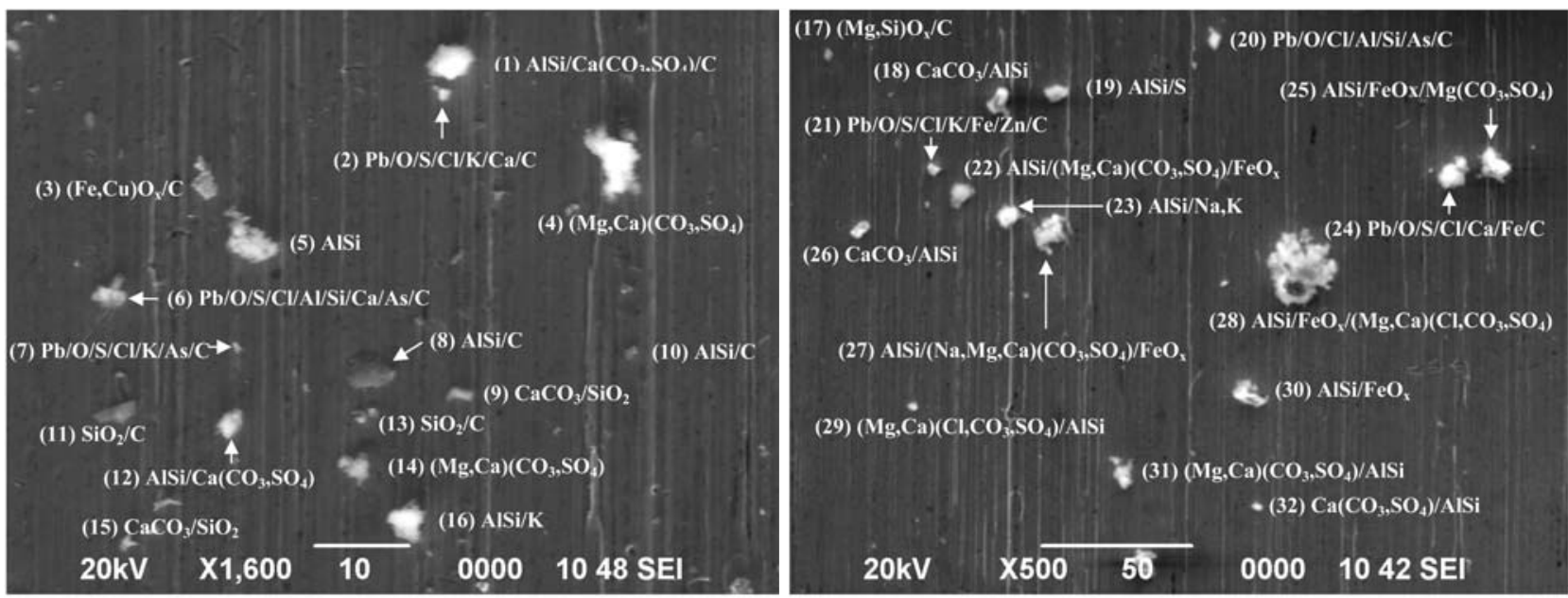

Fig. 1. Exemplar secondary electron images of aerosol sample collected near a lead smelter.

of the near source sample, where the chemical species of each particle is noted together with its particle number. Low- $Z$ particle EPMA can provide quantitative information on the chemical composition, and particles can be classified based on their chemical species. First, a particle was regarded as being composed of a single chemical species when this species constituted at least 90 at.\%. Second, the chemical species were specified even for particles mixed internally with two or more chemical species. Third, as energy dispersive EPMA has high detection limits of $0.1-1.0 \%$ in weight, due mainly to its high Bremsstrahlung background level, the elements at trace levels could not be investigated reliably. Accordingly, elements with concentrations $<1.0$ at.\% were not included in the procedure for chemical speciation (Ro et al., 2000). A unique denotation method was devised to represent the chemical species of internal mixture particles. For example, particle \#4 in Fig. 1, which is an internal mixture of the cations, $\mathrm{Mg}^{2+}$ and $\mathrm{Ca}^{2+}$, and anions, $\mathrm{CO}_{3}{ }^{2-}$ and $\mathrm{SO}_{4}{ }^{2-}$, is denoted as " $(\mathrm{Mg}, \mathrm{Ca})\left(\mathrm{CO}_{3}, \mathrm{SO}_{4}\right)$ ". For particle \#1 in Fig. 1, its chemical species was determined to be an internal mixture of aluminosilicate ("AlSi"), $\mathrm{Ca}\left(\mathrm{CO}_{3}, \mathrm{SO}_{4}\right)$, and carbonaceous species, and the particle is denoted as "AlSi/Ca $\left(\mathrm{CO}_{3}, \mathrm{SO}_{4}\right) / \mathrm{C}$ ".

As shown in the SEIs, particles commonly encountered in the near source sample are mineral dust particles, aged aerosols reacted with $\mathrm{NO}_{\mathrm{x}}$ and $\mathrm{SO}_{\mathrm{x}}$, and metal-containing particles, such as $\mathrm{Pb}, \mathrm{As}, \mathrm{Fe}$, and $\mathrm{Cu}$. Among the metal-containing particles, $\mathrm{Pb}$ - and As-containing particles were assigned when their metal concentrations were $>1$ at. $\%$ because the ambient levels of those $\mathrm{Pb}$ and As metals are quite low. Most particles in the near source sample were mixed with two or more species. Table 2 lists the particle types determined based on their chemical species and morphology, and their encountering frequencies at different particle size bins. For a total of 377 particles analyzed, 15 particle types were classified as carbonaceous particles, such as carbon-rich and organic; mineral dust particles such as aluminosilicates, $\mathrm{AlSi} / \mathrm{misc}, \mathrm{SiO}_{2}, \mathrm{CaCO}_{3}, \mathrm{CaCO}_{3} /$ misc, and $(\mathrm{Ma}, \mathrm{Ca}) \mathrm{CO}_{3}$; aged aerosol particles, such as reacted $\mathrm{CaCO}_{3}$ and $(\mathrm{Mg}, \mathrm{Ca}) \mathrm{SO}_{4} / \mathrm{C} ; \mathrm{Fe}-, \mathrm{Cu}-$, As-, and $\mathrm{Pb}$-containing particles; and fly ash. $\mathrm{Pb}$-containing particles were most abundant in the near source sample. AlSi/misc, $\mathrm{SiO}_{2}$, reacted $\mathrm{CaCO}_{3},(\mathrm{Mg}, \mathrm{Ca}) \mathrm{SO}_{4} / \mathrm{C}$, and $\mathrm{AlSi}+(\mathrm{N}, \mathrm{S})$ were also encountered frequently.

The smallest equivalent diameter of the analyzed particles was $0.32 \mu \mathrm{m}$ with the largest being $19.61 \mu \mathrm{m}$, where the equivalent diameter was calculated by assuming that a particle with the same area for a particle on the SEI was circular. All particles were $<20 \mu \mathrm{m}$ in size with most being within 1-4 $\mu \mathrm{m}$. Particles, $1-2 \mu \mathrm{m}$ in size, were the most abundant with a $30.0 \%$ encountering frequency. Particles, $2-3 \mu \mathrm{m}$ and 3-4 $\mu \mathrm{m}$ in size, had encountering frequencies of $23.6 \%$ and $21.2 \%$, respectively. A similar observation on the size distribution of particles collected in the vicinity of a lead smelter in France was also reported (Choël et al., 2006). Metal-containing particles, such as $\mathrm{Fe}, \mathrm{Cu}$, $\mathrm{As}$, and $\mathrm{Pb}$, were also encountered frequently in the size range of $<4 \mu \mathrm{m}$, most of the aged aerosol particles were 2-4 $\mu \mathrm{m}$ in size, and mineral dust particles were somewhat evenly distributed.

\section{2. 1 Lead-containing Particles}

In our previous single-particle characterization of various ambient aerosol particle samples, it is quite rare to encounter lead-containing particles because the ambient level of lead-containing particles was quite low 
Table 2. Particle types based on their chemical species and morphology and their encountering frequencies in the near source sample.

\begin{tabular}{|c|c|c|c|c|c|c|c|c|c|c|c|}
\hline \multirow{2}{*}{ Particle types } & \multicolumn{11}{|c|}{ Particle size bins } \\
\hline & $\leq 1 \mu \mathrm{m}$ & $1-2 \mu \mathrm{m}$ & $2-3 \mu \mathrm{m}$ & $3-4 \mu \mathrm{m}$ & $4-5 \mu \mathrm{m}$ & $5-6 \mu \mathrm{m}$ & 6-7 $\mu \mathrm{m}$ & $7-8 \mu \mathrm{m}$ & $8-10 \mu \mathrm{m}$ & $>10 \mu \mathrm{m}$ & Sum \\
\hline Carbonaceous & & 6 & 2 & 4 & & 1 & & & & & 13 \\
\hline $\mathrm{AlSi}$ & 1 & 3 & 3 & 3 & 6 & 1 & & 1 & & & 18 \\
\hline AlSi/misc. & 1 & 7 & 8 & 7 & 1 & 1 & 2 & 1 & 3 & & 31 \\
\hline $\mathrm{SiO}_{2}$ & 1 & 11 & 6 & 5 & 3 & 2 & 1 & & & & 29 \\
\hline $\mathrm{CaCO}_{3}$ & 1 & 11 & 6 & 5 & & 1 & & & & & 24 \\
\hline $\mathrm{CaCO}_{3} / \mathrm{misc}$ & & 8 & 3 & 7 & 4 & 2 & 1 & 1 & 1 & 1 & 28 \\
\hline$(\mathrm{Mg}, \mathrm{Ca}) \mathrm{CO}_{3}$ & & 1 & 2 & & 1 & 2 & 1 & & & & 7 \\
\hline Reacted $\mathrm{CaCO}_{3}$ & & 6 & 6 & 8 & 2 & 3 & 2 & 1 & & 1 & 29 \\
\hline$(\mathrm{Mg}, \mathrm{Ca}) \mathrm{SO}_{4} / \mathrm{C}$ & & 9 & 9 & 12 & 4 & 2 & 2 & & 1 & 1 & 40 \\
\hline $\mathrm{AlSi}+(\mathrm{N}, \mathrm{S})$ & & 9 & 16 & 8 & 1 & 1 & 1 & & 3 & & 39 \\
\hline Fe species & & 4 & 8 & 4 & 1 & & 1 & 1 & & 1 & 20 \\
\hline $\mathrm{Cu}$ species & & 5 & 2 & 1 & & & & & & & 8 \\
\hline As species & 3 & 2 & 1 & 1 & 1 & 1 & & 1 & & & 10 \\
\hline $\mathrm{Pb}$ species & 4 & 27 & 16 & 14 & 5 & 1 & 1 & 2 & 1 & 2 & 73 \\
\hline Fly ash & & 3 & 1 & 1 & & & & & & & 5 \\
\hline Others & 2 & 1 & & & & & & & & & 3 \\
\hline Sum & 13 & 113 & 89 & 80 & 29 & 18 & 12 & 8 & 9 & 6 & 377 \\
\hline
\end{tabular}

compared to those of other types of particles, such as mineral dust, sea-salt, carbonaceous particles, bioaerosols, inorganic salts, etc (Geng et al., 2011, 2010, 2009; Maskey et al., 2011; Kim and Ro, 2010; Kim et al., 2010). On the other hand, lead-containing particles were encountered most frequently with relative abundances of $19.4 \%$ (73 among 377 particles) in the near source sample as the sample was collected near the lead smelter. Other studies on particle samples collected nearby and/or at lead smelters also reported high levels of lead-containing particles (Zhang et al., 2009; Murphy et al., 2007; Choël et al., 2006). As mentioned above, lead-containing particles originating from anthropogenic sources appeared mainly in the fine fraction (Zhang et al., 2009; Murphy et al., 2007; Sun et al., 2006; Tan et al., 2006; Wang et al., 2006). Lead-containing particles, less than $2 \mu \mathrm{m}$ in size, in the near source sample were encountered most frequently with relative abundances of $42 \%$. Particles, $2-3 \mu \mathrm{m}$ and $3-4 \mu \mathrm{m}$ in sizes, had relative abundances of $22 \%$ and $19 \%$, respectively, indicating that lead-containing particles collected near the lead smelter were distributed mostly in the fine fraction (see Table 2).

Figs. 2-7 show secondary electron images (SEIs), $\mathrm{X}$-ray spectra, and elemental atomic concentration data of some typical $\mathrm{Pb}$-containing particles encountered in the near smelter sample. Fig. 2(a) shows a SEI of a coagulated particle where the left-part and right-part of the particle composed of $\mathrm{Pb}, \mathrm{Zn}, \mathrm{S}, \mathrm{Cl}$, $\mathrm{K}, \mathrm{C}$, and $\mathrm{O}$ (Fig. 2(b)) and $\mathrm{Al}, \mathrm{Si}, \mathrm{S}, \mathrm{Cl}, \mathrm{C}$, and $\mathrm{O}$ (Fig. 2(c)), respectively. As shown in Fig. 2(a), the atomic concentrations of $\mathrm{Pb}$ and $\mathrm{Zn}$ of the left-part were high (10.7\% and $6.6 \%$, respectively), confirming that the major species are $\mathrm{Pb}$ and $\mathrm{Zn}$ species. On the other hand, significant amounts of $\mathrm{C}, \mathrm{S}, \mathrm{Cl}$, and $\mathrm{K}$ were also observed in the left-part. An analysis of $\mathrm{Pb}$-containing standard particles showed that $\mathrm{Pb}$ species can be carbonated and/or oxidized easily. Moreover, it is somewhat difficult to identify $\mathrm{Pb}$-species based on the elemental concentrations, even though this particle might contain $\mathrm{PbS}, \mathrm{PbSO}_{4}, \mathrm{PbCl}_{2}$, and/or $\mathrm{PbO}$. The right-part particle is mainly aluminosilicate mixed with minor component of $\mathrm{S}$ and $\mathrm{Cl}$. The main source of aluminosilicates is the soil, but sometimes aluminosilicates can be generated as fly-ash during the high temperature combustion process (note its somewhat spherical morphology, which is characteristic of flyash particles.). In addition, it is quite rare for airborne aluminosilicate particles of a soil origin to contain minor $\mathrm{S}$ and $\mathrm{Cl}$ species together. Therefore, this rightpart particle appears to have been emitted from the same source as the left-part particle, i.e. the lead smelter, and coagulated with the left-part particle during the emission process.

Fig. 3(a) shows a SEI of a $\mathrm{Pb}$-containing particle, whose size is quite large (its equivalent diameter is $\sim 5$ $\mu \mathrm{m}$.) and irregular, and which appears to be agglomerated with nano-size particles and chemically heterogeneous. The particle is composed mainly of major $\mathrm{C}$ and $\mathrm{O}$ with minor $\mathrm{Si}, \mathrm{S}$, and $\mathrm{Cl}$ (see Fig. 3(b)). In Fig. 3(c), a fraction of the particle, which appears to contain embedded nano-size particles, contained $\mathrm{Pb}, \mathrm{S}, \mathrm{Cl}, \mathrm{K}$, $\mathrm{C}, \mathrm{O}, \mathrm{Al}$, and $\mathrm{Si}$ elements with major $\mathrm{C}$ and $\mathrm{O}$. Fig. 4(a) shows another type of mixture particles, which is 
(b)

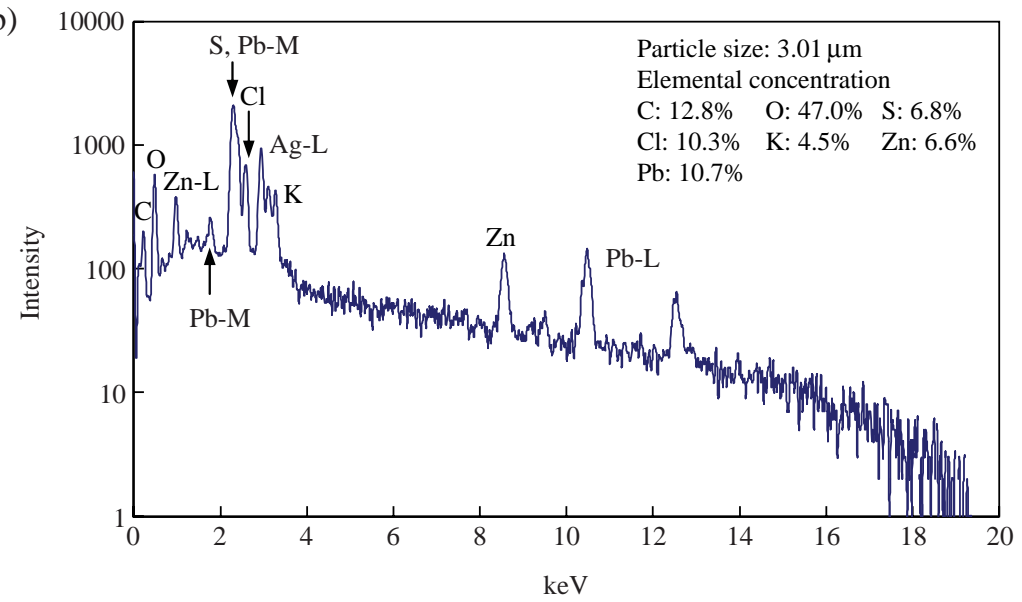

(a)

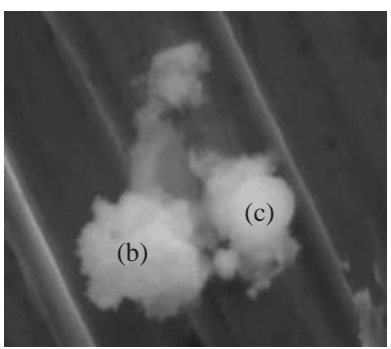

(c)

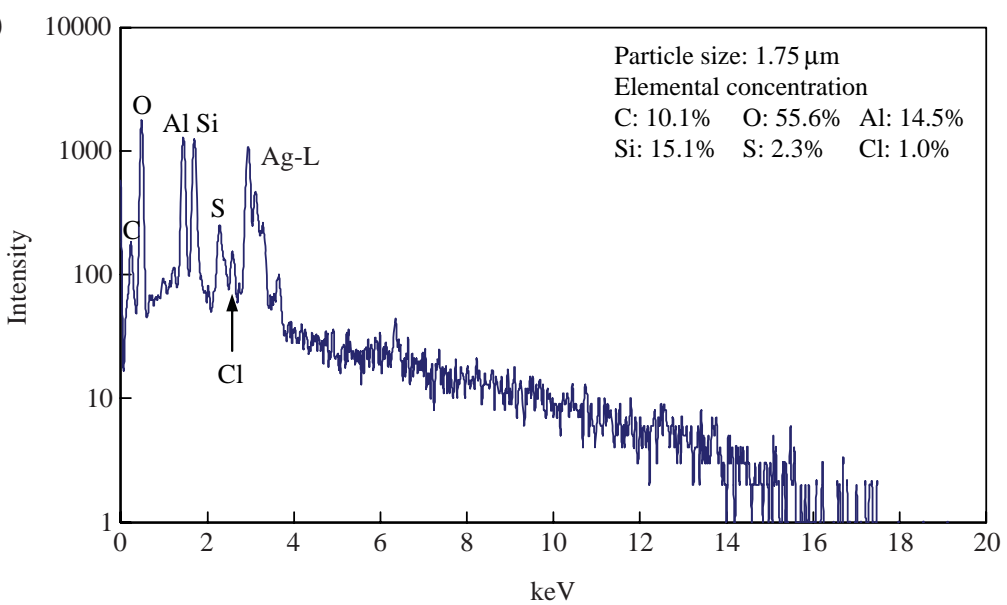

Fig. 2. Secondary electron image, $\mathrm{X}$-ray spectra, and elemental atomic concentrations of a $\mathrm{Pb}$-containing particle.

a micrometer-size particle ((b) in Fig. 4(a)) containing embedded nano-size particles appearing brighter in their SEI (see a nano-size particle notated as (c) in Fig. 4(a)). This particle was also composed of major $\mathrm{C}$ and $\mathrm{O}$ with minor $\mathrm{S}$ and $\mathrm{Cl}$ (Fig. 4(b)), and nano-size particles were composed of major $\mathrm{C}$ and $\mathrm{O}$ with minor $\mathrm{Pb}, \mathrm{S}$, and $\mathrm{Cl}$, indicating that $\mathrm{Pb}$-containing particles were embedded in other types of particles during the emission process. The particles shown in Figs. 2-4 appear irregular, and are composed mainly of $\mathrm{C}$ and $\mathrm{O}$ with minor $\mathrm{Pb}, \mathrm{S}, \mathrm{Cl}, \mathrm{K}, \mathrm{Al}$ and/or $\mathrm{Si}$ in atomic fraction. Most $\mathrm{Pb}$-containing particles were mixed internally with other chemical species, either by coagulation or embedding. Although the particles were collected near the lead smelter, the $\mathrm{Pb}$ atomic concentrations of the $\mathrm{Pb}$-containing particles were not that high (mostly less than 5\%). On the other hand, the mass concentrations would be much higher for $\mathrm{Pb}$ because the atomic weight of $\mathrm{Pb}$ is much larger than those of the other elements.
The SEIs shown in Figs. 5 and 6 indicate that the Pbcontaining particles were generated by a high temperature combustion process, as recognized by their spherical morphology. They are composed of $\mathrm{Pb} / \mathrm{Zn} / \mathrm{K} / \mathrm{Cl} /$ $\mathrm{Si} / \mathrm{Al} / \mathrm{O} / \mathrm{C}$ and $\mathrm{Pb} / \mathrm{Cl} / \mathrm{S} / \mathrm{O} / \mathrm{C}$, respectively, with a $\mathrm{Pb}$ content of $>10$ atomic \%. The particle shown in Fig. 7 is lead-rich containing a high lead content throughout the entire particle despite its large size of approximately $12 \mu \mathrm{m}$. Particles were considered "lead-rich" particles when the lead content was $>10$ at.\%. Other studies reported that those lead-rich particles tend to be smaller than the other $\mathrm{Pb}$-containing particles, suggesting that $\mathrm{Pb}$-containing particles could be aged from leadrich particles after being mixed with other species (Zhang et al., 2009; Murphy et al., 2007; Choël et al., 2006). On the other hand, many of the lead-rich particles were large in the present study, suggesting that this near smelter sample contains many fresh lead-rich particles due to the short distance of the sampling site from the lead smelter. 
(b)

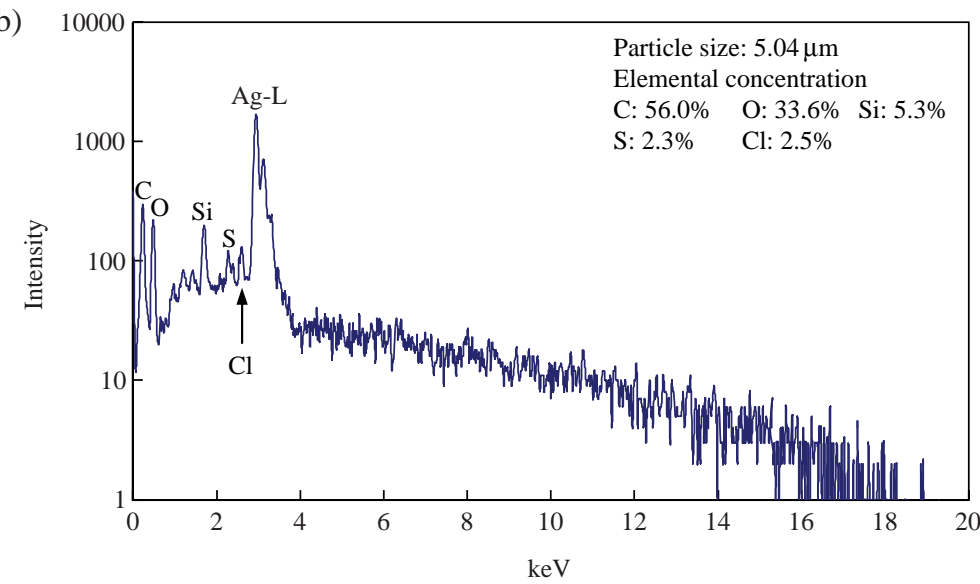

(a)

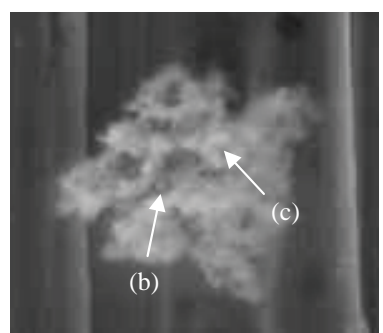

(c)

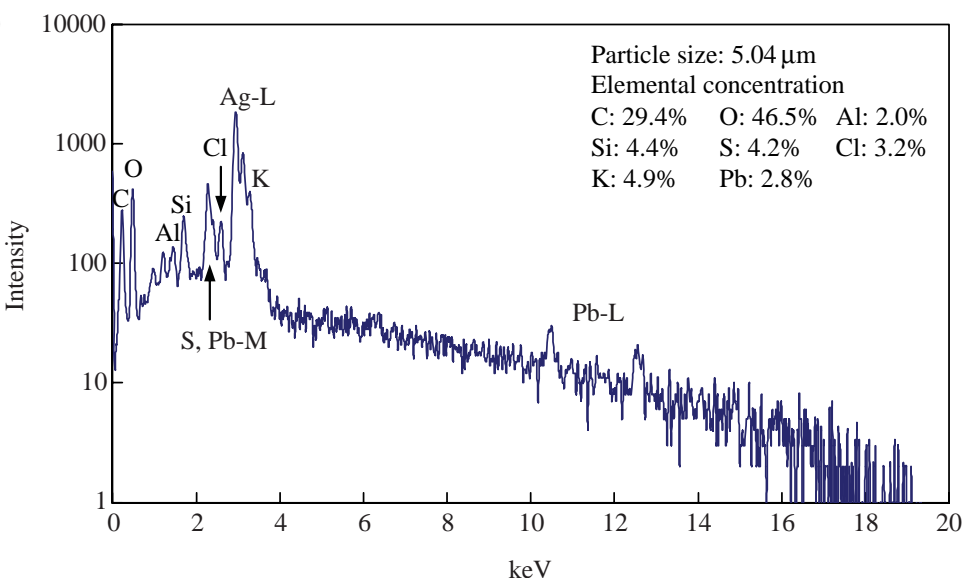

Fig. 3. Secondary electron image, $\mathrm{X}$-ray spectra, and elemental atomic concentrations of a Pb-containing particle.

As shown for the above exemplar $\mathrm{Pb}$-containing particles, the elemental lead concentration data obtained by low- $Z$ particle EPMA were not sufficient to clearly identify the $\mathrm{Pb}$ chemical species because there are many other chemical species in the $\mathrm{Pb}$-containing particles. Therefore, $\mathrm{Pb}$-containing particles were classified according to the chemical elements detected, which are listed in Table 3. Among the various lead-containing particle types, $\mathrm{Pb} / \mathrm{O} / \mathrm{S} / \mathrm{Cl} / \mathrm{K} / \mathrm{Ca} / \mathrm{C} /$ misc and $\mathrm{Pb} / \mathrm{O} /$ $\mathrm{S} / \mathrm{Cl} / \mathrm{K} / \mathrm{C} /$ misc types were encountered often. Sulfur was detected in $88 \%$ of the $\mathrm{Pb}$-containing particles, which can be from natural soil minerals, such as anglesite $\left(\mathrm{PbSO}_{4}\right)$ and galena (PbS) (Zhang et al., 2009; Tan et al., 2006; Greenwood and Earnshaw, 1984). On the other hand, sulfur can be entrained in $\mathrm{Pb}$-containing particles as sulfates, which were formed by the oxidation of $\mathrm{SO}_{2}$ generated in the refining process of lead smelters, which is more probable for this sample collected near the lead smelter (Li et al., 2003; Sobanska et al., 1999). In addition, $\mathrm{Pb}$-particles containing chlorine were encountered with an encountering frequency of $85 \%$. This suggests that the chlorine species can exist as $\mathrm{PbCl}_{2}$, which has been reported to be generated by a reaction of $\mathrm{HCl}$ and $\mathrm{Pb}$ during the combustion process (Zhang et al., 2009; Green berg et al., 1978). $\mathrm{C}, \mathrm{K}, \mathrm{Ca}, \mathrm{As}, \mathrm{Fe}$, and $\mathrm{Zn}$ were observed frequently in $\mathrm{Pb}$-containing particles, which might be entrained during the lead refining process of $\mathrm{Pb}$ ore, even though their entrainment processes were unclear.

Several studies on the chemical species of airborne lead-containing particles have been carried out at various sites around the world. Lead species observed in samples collected at lead smelters in France were reported to be mainly $\mathrm{PbSO}_{4}$, with other $\mathrm{PbS}, \mathrm{PbSO}_{4}$ - $\mathrm{PbO}$, and $\mathrm{Pb}$ metal species, as determined by microRaman spectrometry (Choël et al., 2006; Batonneau et al., 2004; Sobanska et al., 1999). The airborne leadcontaining particles collected in Shanghai (China) were mainly $\mathrm{PbCl}_{2}, \mathrm{PbSO}_{4}$, and $\mathrm{PbO}$ (Tan et al., 2006). In Manchester, the major lead species collected in road dust sediments were reported to be $\mathrm{PbCrO}_{4}, \mathrm{~Pb}$-sorbed goethite, $\mathrm{PbO}, \mathrm{PbCl}_{2}$, and $\mathrm{Pb}$ carbonates (Barrett et al., 
(b)

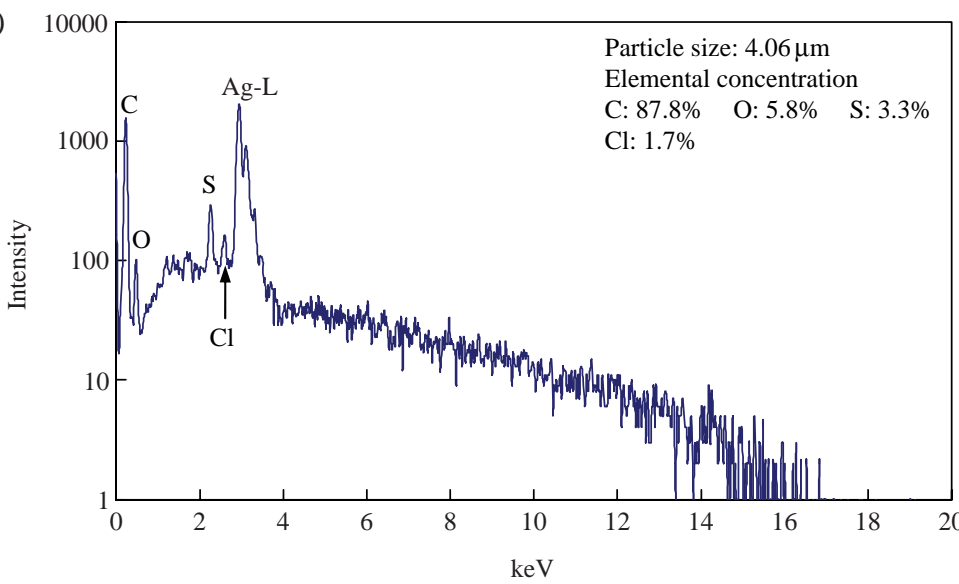

(a)

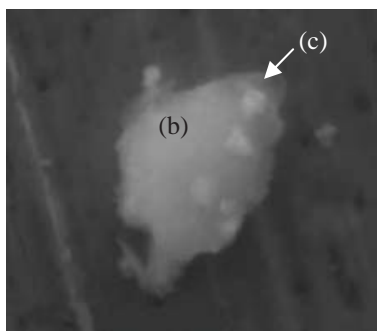

(c)

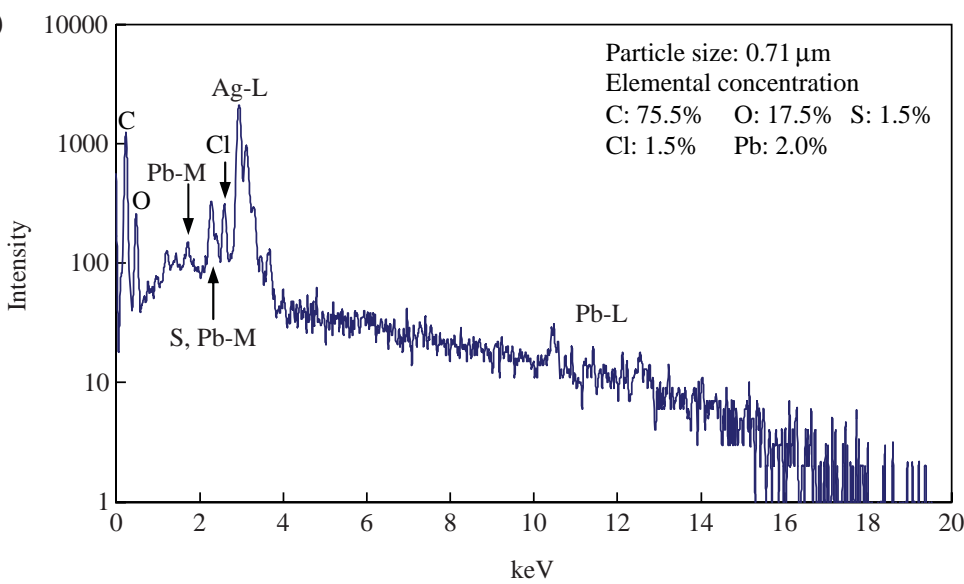

Fig. 4. Secondary electron image, $\mathrm{X}$-ray spectra, and elemental atomic concentrations of a $\mathrm{Pb}$-containing particle.
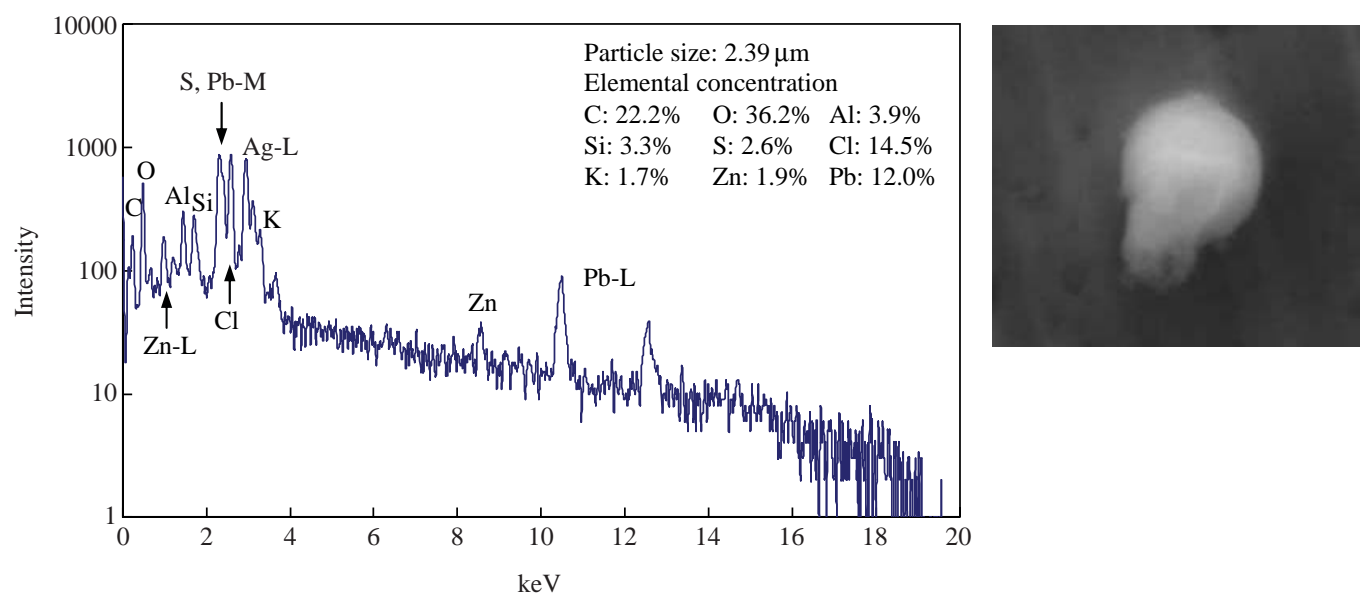

Fig. 5. Secondary electron image, $\mathrm{X}$-ray spectrum, and elemental atomic concentrations of a $\mathrm{Pb}$-containing particle.

2010). Ishizaka et al. (2009) reported that $\mathrm{PbO}, \mathrm{PbSO}_{4}$, $\mathrm{PbCl}_{2}$, and $\mathrm{PbCO}_{3}$ particles were observed in the samples collected in Korea and Japan during Asian dust storm events and $\mathrm{PbCO}_{3}$ particles can be generated by a reaction of $\mathrm{CaCO}_{3}$ and $\mathrm{PbSO}_{4}$ in the aqueous phase. Although previous studies reported that airborne $\mathrm{Pb}$ - 

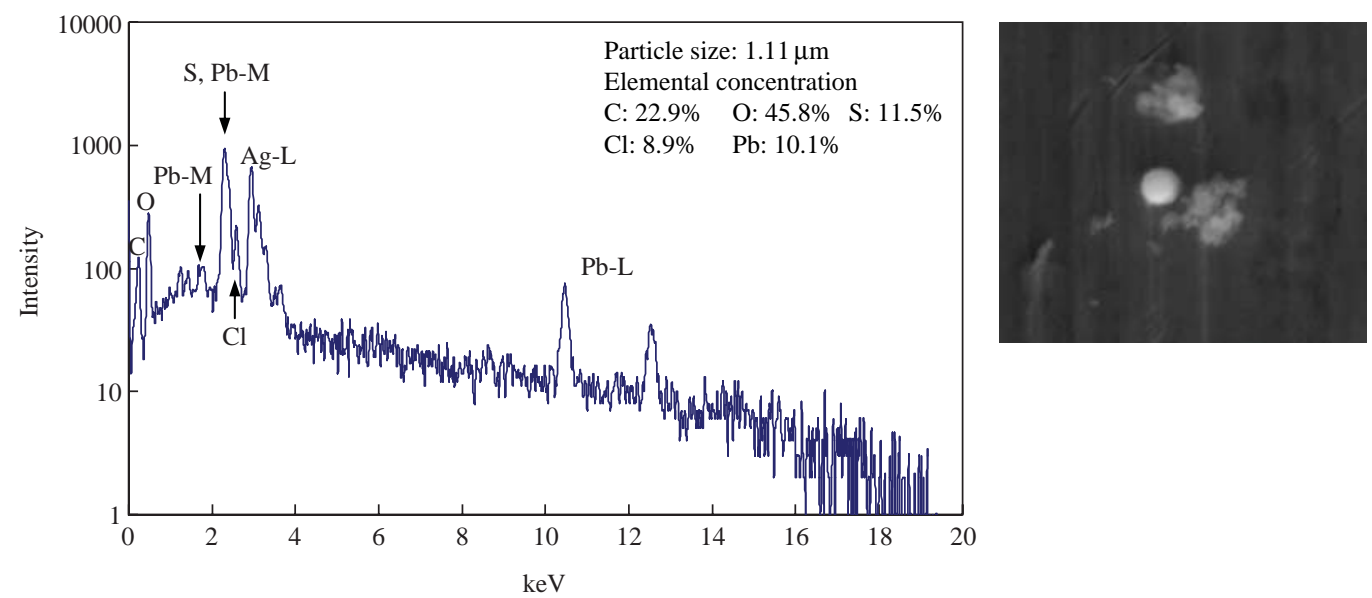

Fig. 6. Secondary electron image, X-ray spectrum, and elemental atomic concentrations of a Pb-containing particle.
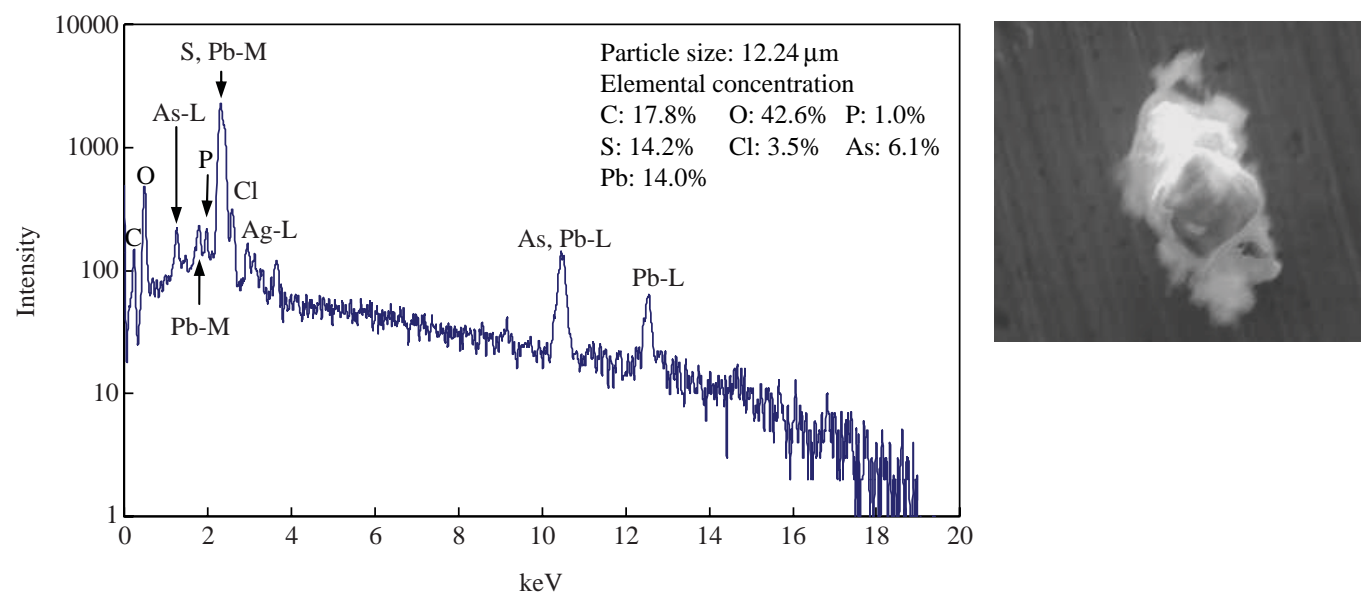

Fig. 7. Secondary electron image, $\mathrm{X}$-ray spectrum, and elemental atomic concentrations of a Pb-containing particle.

containing particles were mainly $\mathrm{PbSO}_{4}, \mathrm{PbS}, \mathrm{PbO}$, $\mathrm{PbCl}_{2}$, and $\mathrm{PbCO}_{3}$, the chemical speciation of the $\mathrm{Pb}-$ containing particles is somewhat difficult, according to low- $Z$ particle EPMA. On the other hand, it is clear that the $\mathrm{Pb}$-containing particles are complicated mixtures containing a range of chemical species including $\mathrm{C}, \mathrm{S}, \mathrm{Cl}, \mathrm{Ca}, \mathrm{K}, \mathrm{Zn}, \mathrm{As}$, and/or Fe.

\section{2. 2 Mineral Dust Particles}

A range of mineral dust particles were encountered in the near source sample. The number of $\mathrm{CaCO}_{3}$-containing particles, such as $\mathrm{CaCO}_{3}, \mathrm{CaCO}_{3} / \mathrm{misc}$, and $(\mathrm{Mg}, \mathrm{Ca}) \mathrm{CO}_{3}$, was 59 among a total of 377 particles analyzed, which are the most abundant minerals with a relative abundance of $15.6 \%$. This was followed by AlSi-containing and $\mathrm{SiO}_{2}$ particles with relative abundances of $13.0 \%$ and $7.7 \%$, respectively (Table 2). Aluminosilicate particles can exist as a variety of min- erals, such as feldspar, montmorllonite, muscovite, kaolinite, etc (Jung et al., 2010). On the other hand, the specific mineralogy of aluminosilicate particles cannot be performed unambiguously based only on their X-ray spectral data. Accordingly, aluminosilicate particles are just classified as "AlSi" particles. When aluminosilicate particles are mixed with other chemical components, they are classified as AlSi/misc.

These $\mathrm{CaCO}_{3}$-containing and AlSi-containing particles are generally considered to be of a soil origin and particles of soil origin are generally large. On the other hand, $\mathrm{CaCO}_{3}$-containing and $\mathrm{SiO}_{2}$ particles in a size of 1-2 $\mu \mathrm{m}$ were the most abundant (Table 2), which are relatively small for them to be sourced only from the soil. In addition, the more abundant observation of $\mathrm{CaCO}_{3}$-containing particles than aluminosilicates suggests that $\mathrm{CaCO}_{3}$-containing particles are from sources other than soil because the content of alumino- 
Table 3. Different types of $\mathrm{Pb}$-containing particles and their encountering frequencies.

\begin{tabular}{lclc}
\hline \multicolumn{1}{c}{ Chemical species } & Number of particles & \multicolumn{1}{c}{ Chemical species } & Number of particles \\
\hline $\mathrm{Pb} / \mathrm{S} / \mathrm{Cl}$ & 1 & $\mathrm{~Pb} / \mathrm{O} / \mathrm{S} / \mathrm{Cl} / \mathrm{Ca} / \mathrm{As} / \mathrm{C}$ & 3 \\
$\mathrm{~Pb} / \mathrm{O} / \mathrm{S}$ & 2 & $\mathrm{~Pb} / \mathrm{O} / \mathrm{C} / \mathrm{Ca} / \mathrm{As} / \mathrm{C} / \mathrm{misc}$ & 1 \\
$\mathrm{~Pb} / \mathrm{O} / \mathrm{S} / \mathrm{C}$ & 4 & $\mathrm{~Pb} / \mathrm{O} / \mathrm{S} / \mathrm{Cl} / \mathrm{As} / \mathrm{C}$ & 2 \\
$\mathrm{~Pb} / \mathrm{O} / \mathrm{S} / \mathrm{Cl} / \mathrm{Pb} / \mathrm{O} / \mathrm{Cl} / \mathrm{As} / \mathrm{Zn} / \mathrm{C}$ & 2 \\
$\mathrm{~Pb} / \mathrm{O} / \mathrm{S} / \mathrm{Cl} / \mathrm{C}$ & 1 & $\mathrm{~Pb} / \mathrm{O} / \mathrm{S} / \mathrm{K} / \mathrm{Ca} / \mathrm{C} / \mathrm{misc}$ & 1 \\
$\mathrm{~Pb} / \mathrm{O} / \mathrm{S} / \mathrm{Cl} / \mathrm{K} / \mathrm{C} / \mathrm{misc}$ & 5 & $\mathrm{~Pb} / \mathrm{O} / \mathrm{C} / \mathrm{misc}$ & 1 \\
$\mathrm{~Pb} / \mathrm{O} / \mathrm{S} / \mathrm{Cl} / \mathrm{K} / \mathrm{Ca} / \mathrm{C} / \mathrm{misc}$ & $\mathrm{Pb} / \mathrm{O} / \mathrm{Fe}$ & 1 \\
$\mathrm{~Pb} / \mathrm{O} / \mathrm{S} / \mathrm{Cl} / \mathrm{K} / \mathrm{Ca} / \mathrm{Fe} / \mathrm{C} / \mathrm{misc}$ & $\mathrm{Pb} / \mathrm{O} / \mathrm{Ca} / \mathrm{Fe}$ & 1 \\
$\mathrm{~Pb} / \mathrm{O} / \mathrm{S} / \mathrm{Cl} / \mathrm{K} / \mathrm{Ca} / \mathrm{As} / \mathrm{C}$ & 8 & $\mathrm{~Pb} / \mathrm{O} / \mathrm{Cl} / \mathrm{Fe} / \mathrm{C}$ & 1 \\
$\mathrm{~Pb} / \mathrm{O} / \mathrm{S} / \mathrm{Cl} / \mathrm{K} / \mathrm{Ca} / \mathrm{As} / \mathrm{C} / \mathrm{misc}$ & $\mathrm{Pb} / \mathrm{O} / \mathrm{Cl} / \mathrm{K} / \mathrm{Zn} / \mathrm{C} / \mathrm{misc}$ & 1 \\
$\mathrm{~Pb} / \mathrm{O} / \mathrm{S} / \mathrm{Cl} / \mathrm{K} / \mathrm{Ca} / \mathrm{As} / \mathrm{Fe} / \mathrm{C} / \mathrm{misc}$ & $\mathrm{Pb} / \mathrm{O} / \mathrm{As} / \mathrm{C} / \mathrm{misc}$ & 1 \\
$\mathrm{~Pb} / \mathrm{O} / \mathrm{S} / \mathrm{Cl} / \mathrm{K} / \mathrm{As} / \mathrm{C} / \mathrm{misc}$ & 5 & $\mathrm{~Pb} / \mathrm{O} / \mathrm{Cl} / \mathrm{As}$ & 1 \\
$\mathrm{~Pb} / \mathrm{O} / \mathrm{S} / \mathrm{Cl} / \mathrm{K} / \mathrm{Zn} / \mathrm{C}$ & 6 & $\mathrm{~Pb} / \mathrm{O} / \mathrm{Cl} / \mathrm{Ca} / \mathrm{As} / \mathrm{C}$ & 1 \\
$\mathrm{~Pb} / \mathrm{O} / \mathrm{S} / \mathrm{Cl} / \mathrm{K} / \mathrm{Zn} / \mathrm{Fe} / \mathrm{C}$ & 1 & $\mathrm{~Pb} / \mathrm{O} / \mathrm{Cl} / \mathrm{K} / \mathrm{Ca} / \mathrm{As} / \mathrm{C} / \mathrm{misc}$ & \\
$\mathrm{Pb} / \mathrm{O} / \mathrm{S} / \mathrm{Cl} / \mathrm{Ca} / \mathrm{C} / \mathrm{misc}$ & $\mathrm{Total}$ & 73 \\
\hline
\end{tabular}

silicate minerals is much higher than that of $\mathrm{CaCO}_{3}$ minerals. $\mathrm{SiO}_{2}, \mathrm{CaCO}_{3}$, and $\mathrm{Fe}_{2} \mathrm{O}_{3}$ are added during an ore grilling process, which is one of the pyro-metallurgical processes performed in lead smelters, to obtain a high yield (Sobanske et al., 1999). This can be related to the present observations, such that some $\mathrm{Pb}$-containing particles contain $\mathrm{Ca}$ and/or Fe (Table 3). Several studies also reported that the relatively small size $\mathrm{CaCO}_{3}$ particles can be generated from incineration (Hwang and Ro, 2006; Fermo et al., 2000; Speiser et al., 2000).

\section{2. 3 Nitrate and/or Sulfate Particles}

Sulfate and/or nitrate particles (mostly sulfates) were also encountered in the near source samples. The overall relative abundance of these sulfate and/or nitrate particles was $28.6 \%$, and were mainly mineral dust particles that reacted with nitrate and sulfate, such as reacted $\mathrm{CaCO}_{3},(\mathrm{Mg}, \mathrm{Ca}) \mathrm{SO}_{4} / \mathrm{C}$, and $\mathrm{AlSi}+(\mathrm{N}, \mathrm{S})$ (Table 2). Nitrate and/or sulfate particles are the most abundant in the 2-4 $\mu \mathrm{m}$ size range. As mentioned above, these sulfate particles are most likely the result of $\mathrm{SO}_{2}$ oxidation in the refining process of a lead smelter $(\mathrm{Li}$ et al., 2003; Sobanska et al., 1999).

\section{2. 4 Metal-containing Particles}

In the near source sample, metal-containing particles were encountered frequently. As stated above, the most common species were lead-containing particles with a relative abundance of $19.3 \%$. Iron, arsenic and copper-containing particles were also encountered with relative abundances of $5.3 \%, 2.7 \%$, and $2.1 \%$, respectively. These metal-containing particles normally appeared irregular. Their size was mostly smaller than 4 $\mu \mathrm{m}$ with particles $<2 \mu \mathrm{m}$ in size comprising a considerable proportion. Although $\mathrm{Zn}$ species are not listed in Table 2 as a chemical type, the $\mathrm{Zn}$ component was also observed in some of lead-containing particles (Table 3). Iron-containing particles, which are generated by soil dust, industrial operations, exhaust from combustion engines, etc (Zhang et al., 2009; Flament et al., 2008; Seinfeld, 1986), were next in abundance to lead-containing particles. On the other hand, Fe-containing particles may be from the $\mathrm{Fe}_{2} \mathrm{O}_{3}$ added for a higher yield during the ore grilling process. The relative abundance of arsenic and copper containing particles was quite low $(<5 \%)$, but much higher than those in ambient aerosol samples (Geng et al., 2010, 2009; Kim and Ro, 2010; Kim et al., 2010), which were reported to be detected normally in non-ferrous metallurgical emission (Mattielli et al., 2009; Choël et al., 2006; Batonneau et al., 2004; Sobanska et al., 1999). These various metal components appear to be unique signatures of the particles collected near a lead smelter that are generated during the smelting process of lead. On average, refined ores were reported to contain $60-75 \%$ lead $(\mathrm{PbS}), 3-10 \%$ zinc $(\mathrm{ZnS})$, and 0.5 $1 \%$ copper $(\mathrm{CuS})$ with $\mathrm{Bi}, \mathrm{Cd}, \mathrm{Sb}, \mathrm{As}$ and $\mathrm{Sn}$ at trace levels $(<0.3 \%)$ (Sobanska et al., 1999).

\section{2.5 Fly-ash Particles}

As the smelting process is a typical industrial combustion process, spherical fly-ash particles generated in a high-temperature process were observed in the near source sample with a distribution of approximately $5 \%$. Fly-ash particles are easily distinguishable on their SEIs due to their spherical morphology. As they were generated during combustion, their size was relatively small, mostly $<4 \mu \mathrm{m}$, and the major chemical components were aluminosilicates mixed with a small amount of $\mathrm{Ca}, \mathrm{Fe}$, and $\mathrm{C}$. Some of the fly ash particles contained lead.

\section{2.6 Carbonaceous Particles}

The speciation of carbonaceous particles based on their X-ray spectral data is difficult because EPMA cannot detect hydrogen. On the other hand, the parti- 
cles are identified as carbonaceous particles when the sum of the $\mathrm{C}$ and $\mathrm{O}$ contents of particles in the atomic fraction is $>90 \%$. Among the carbonaceous particles, carbon-rich particles are differentiated from organic particles when their carbon content is 3-times higher than the oxygen content (Ro et al., 2000). Among the carbonaceous particles, carbon-rich particles, which are mostly $<4 \mu \mathrm{m}$ in size, are encountered more frequently than organic particles. These carbon-rich particles were reported to be generated by a range of combustion processes (Geng et al., 2010; Zhang et al., 2009; Wang et al., 2006). Although their distribution is approximately $3 \%$ in the near source sample, most particles, regardless of their major chemical species, were mixed with a considerable amount of $\mathrm{C}$ and $\mathrm{O}$, which also suggests that carbonaceous species were generated during the combustion process.

\section{CONCLUSIONS}

The chemical compositions and size distributions of airborne aerosol particles collected near a lead smelter were analyzed by low $-Z$ particle EPMA. Individual standard particles, such as $\mathrm{PbO}, \mathrm{PbS}, \mathrm{PbSO}_{4}, \mathrm{PbCl}_{2}$, and $\mathrm{PbCO}_{3}$, were examined to help identify the leadcontaining aerosol particles. An examination of $\mathrm{PbS}$ and $\mathrm{PbSO}_{4}$ standard particles confirmed that low- $Z$ particle EPMA can separate the $\mathrm{Pb}$ M-line and $\mathrm{S} \mathrm{K}$ line, resulting in a good estimation of the elemental concentrations of $\mathrm{S}$ and $\mathrm{Pb}$. For the near smelter sample, lead-containing particles were observed most abundantly with a relative abundance of $19.4 \%$. This means that airborne particles around lead smelters were affected by the emissions from the lead smelter. Lead-containing particles were mixed frequently with other species ( $\mathrm{S}, \mathrm{Cl}, \mathrm{K}, \mathrm{Ca}$, and/or $\mathrm{C}$ ) as well as $\mathrm{As}, \mathrm{Fe}$, and $\mathrm{Zn}$. $\mathrm{CaCO}_{3}$-containing, carbonaceous, metal-containing, nitrates, sulfates and fly-ash particles are also believed to have been influenced by lead smelters, where these particles were abundant in the fine fraction. Although airborne particles collected near the lead smelter contain elevated lead levels, the other type of particles, such as $\mathrm{CaCO}_{3}$-containing, carbonaceous, metal-containing, nitrates, sulfates, and fly-ash particles, were found to be unique signatures for a sample influenced by the emissions from lead smelters.

\section{ACKNOWLEDGEMENT}

This research was supported by Basic Science Research Program through the National Research Foundation of Korea (NRF) funded by the Ministry of Educa- tion, Science, and Technology (2010-0018881) and by the fund of National Science Foundation of China (NSFC; project 20477042).

\section{REFERENCES}

Barrett, J., Taylor, K., Hudson-edwards, K., Charnock, J. (2010) Solid-Phase Speciation of Pb in Urban Road Dust Sediment: A XANES and EXAFS Study. Environmental Science and Technology 44, 2940-2946.

Batonneau, Y., Bremard, C., Gengembre, L., Laureyns, J., Maguer, A.L., Maguer, D.L., Perdrix, E., Sobanska, S. (2004) Speciation of $\mathrm{PM}_{10}$ Sources of Airborne Nonferrous Metals within the 3-km Zone of Lead/Zinc Smelters. Environmental Science and Technology 38, 5281-5289.

Bowers, T., Beck, B. (2006) What is the meaning of nonlinear dose-response relationships between blood lead concentrations and IQ? Neurotoxicology 27, 520-524.

Choël, M., Deboudt, K., Flament, P., Lecornet, G., Perdrix, E., Sobanska, S. (2006) Fast evolution of tropospheric $\mathrm{Pb}$ - and $\mathrm{Zn}$-rich particles in the vicinity of a lead smelter. Atmospheric Environment 40, 4439-4449.

Donaldson, K., Stone, V., Seaton, A., MacNee, W. (2001) Ambient particle inhalation and the cardiovascular system: potential mechanisms. Environmental Health Perspectives 109(suppl 4), 523-527.

Fermo, P., Cariati, F., Pozzi, A., Tettamanti, M., Collina, E., Pitea, D. (2000) Analytical characterization of municipal solid waste incinerator fly ash: Part II, Fresenius'. Journal of Analytical Chemistry 366, 267-272.

Flament, P., Mattielli, N., Aimoz, L., Choël, M., Deboudt, K., de Jong, J., Rimetz-Planchon, J., Weis, D. (2008) Iron isotopic fractionation in industrial emissions and urban aerosols. Chemosphere 73, 1793-1798.

Fulton, M., Thomson, G., Hunter, R., Raab, G., Laxen, D., Hepb, W. (1987) Influence of blood lead on the ability and attainment of children in edinburgh. The Lancet 329, 1221-1226.

Geng, H., Park, Y.-M., Hwang, H., Kang, S., Ro, C.-U. (2009) Elevated nitrogen-containing particles observed in Asian dust aerosol samples collected at the marine boundary layer of the Bohai Sea and the Yellow Sea. Atmospheric Chemistry and Physics 9, 6933-6947.

Geng, H., Ryu, J., Jung, H.-J., Chung, H., Ahn, K.-H., Ro, C.-U. (2010) Single-Particle Characterization of Summertime Arctic Aerosols Collected at Ny-Ålesund, Svalbard. Environmental Science and Technology 44, 2348-2353.

Geng, H., Ryu, J., Maskey, S., Jung, H.-J., Ro, C.-U. (2011) Characterization of individual aerosol particles collected during a haze episode in Incheon, Korea using the quantitative ED-EPMA technique. Atmospheric Chemistry and Physics 11, 1327-1337.

Green berg, R., Zoller, W., Gordon, G. (1978) Composition and size distributions of particles released in refuse 
incineration. Environmental Science and Technology 12, 566-573.

Greenwood, N.N., Earnshaw, A. (1984) Chemistry of the Elements. Pergamon Press Oxford, New York.

He, K., Yang, F., Ma, Y., Zhang, Q., Yao, X., Chan, C.K., Cadle, S., Chan, T., Mulawa, P. (2001) The characteristics of $\mathrm{PM}_{2.5}$ in Beijing, China. Atmospheric Environment 35, 4959-4970.

Hilary, A.G. (2001) The biological chemistry of lead. Current Opinion in Chemical Biology 5, 223-227.

Hu, W., Wu, G.P. (1999) The lead pollution level in particulate of the four cities in China. Environmental Monitoring in China 15, 5-7.

Hwang, H.-J., Ro, C.-U. (2006) Single-particle characterization of municipal solid waste (MSW) ash particles using low- $Z$ particle electron probe $\mathrm{X}$-ray microanalysis. Atmospheric Environment 40, 2873-2881.

Ishizaka, T., Tohno, S., Ma, C.-J., Morikawa, A., Takaoka, M., Nishiyama, F., Yamamoto, K. (2009) Reactivity between $\mathrm{PbSO}_{4}$ and $\mathrm{CaCO}_{3}$ particles relevant to the modification of mineral particles and chemical forms of $\mathrm{Pb}$ in particles sampled at two remote sites during an Asian dust event. Atmospheric Environment 43, 2550-2560.

Jung, H.-J., Malek, M.A., Ryu, J., Kim, B., Song, Y.-C., Kim, H., Ro, C.-U. (2010) Speciation of individual mineral particles of micrometer size by the combined use of attenuated total reflectance-fourier transforminfrared imaging and quantitative energy-dispersive electron probe X-ray microanalysis techniques. Analytical Chemistry 82, 6193-6202.

Kim, B., Jung, H.-J., Song, Y.-C., Lee, M., Kim, H., Kim, J., Sohn, J., Ro, C.-U. (2010) Characterization of Summertime Aerosol Particles Collected at Subway Stations in Seoul, Korea Using Low-Z Particle Electron Probe X-ray Microanalysis. Asian Journal of Atmospheric Environment 4, 97-105.

Kim, H., Ro, C.-U. (2010) Characterization of Individual Atmospheric Aerosols Using Quantitative Energy Dispersive-Electron Probe X-ray Microanalysis: A Review. Asian Journal of Atmospheric Environment 4, 115-140.

Li, Q.-H., Guo, X.-Y., Xiao, S.-W., Huang, K., Zhang, D.-M. (2003) Life cycle inventory analysis of $\mathrm{CO}_{2}$ and $\mathrm{SO}_{2}$ emission of imperial smelting process for $\mathrm{Pb}-\mathrm{Zn}$ smelter. Journal of Central South University of Technology 10, 108-112.

Löndahl, J., Massling, A., Pagels, J., Swietlicki, E., Vaclavik, E., Loft, S. (2007) Size-resolved respiratory-tract deposition of fine and ultrafine hydrophobic and hygroscopic aerosol particles during rest and exercise. Inhalation Toxicology 19, 109-116.

Maskey, S., Kang, T., Jung, H.-J., Ro, C.-U. (2011) Singleparticle characterization of indoor aerosol particles collected at an underground shopping area in Seoul, Korea. Indoor Air 21, 12-24.

Mattielli, N., Petit, J., Deboudt, K., Flament, P., Perdrix, E., Taillez, A., Rimetz-Planchon, J., Weis, D. (2009) $\mathrm{Zn}$ isotope study of atmospheric emissions and dry depositions within a $5 \mathrm{~km}$ radius of a $\mathrm{Pb}-\mathrm{Zn}$ refinery. Atmospheric Environment 43, 1265-1272.

Murphy, D., Hudson, P., Cziczo, D., Gallavardin, S., Froyd, K., Johnston, M., Middlebrook1, A., Reinard, M., Thomson, D., Thornberry, T., Wexler, A. (2007) Distribution of lead in single atmospheric particles. Atmospheric Chemistry and Physics 7, 3195-3210.

Nemmar, A., Hoet, P.H.M., Vanquickenborne, B., Dinsdale, D., Thomeer, M., Hoylaerts, M.F., Vanbilloen, H., Mortelmans, L., Nemery, B. (2002) Passage of inhaled particles into the blood circulation in humans. Circulation 105, 411-414.

Oberdörster, G. (2001) Pulmonary effects of inhaled ultrafine particles. International Archives of Occupational and Environmental Health 74, 1-8.

Papanikolaou, N.C., Hatzidaki, E.G., Belivanis, S., Tzanakakis, G.N., Tsatsakis, A.M. (2005) Lead toxicity update: a brief review. Medical Science Monitor 11, RA329RA336.

Ro, C.-U., Kim, H., VanGrieken, R. (2004) An Expert System for Chemical Speciation of Individual Particles Using Low-Z Particle Electron Probe X-ray Microanalysis Data. Analytical Chemistry 76, 1322-1327.

Ro, C.-U., Oh, K.-Y., Kim, H., Chun, Y.-S., Osan, J., de Hoog, J., Van Grieken, R. (2001) Chemical speciation of individual atmospheric particles using low- $Z$ electron probe X-ray microanalysis: characterizing "Asian Dust" deposited with rainwater in Seoul, Korea. Atmospheric Environment 35, 4995-5005.

Ro, C.-U., Osan, J., Szaloki, I., de Hoog, J., Worobiec, A., Van Grieken, R. (2003) A Monte Carlo Program for Quantitative Electron induced X-ray Analysis of Individual Particles. Analytical Chemistry 75, 851-859.

Ro, C.-U., Osan, J., Szaloki, I., Van Grieken, R. (2000) Determination of Chemical Species in Individual Aerosol Particles Using Ultra-thin Window EPMA. Environmental Science and Technology 34, 3023-3030.

Ro, C.-U., Osan, J., Van Grieken, R. (1999) Determination of Low-Z Elements in Individual Environmental Particles Using Window less EPMA. Analytical Chemistry $71,1521-1528$.

Schwartz, J. (2001) Air Pollution and Blood Markers of Cardiovascular Risk. Environmental Health Perspectives 109, 405-409.

Seaton, A., MacNee, W., Donaldson, K., Goddon, D. (1995) Particulate air pollution and acute health effects. The Lancet 345, 176-178.

Seinfeld, J. (1986) Atmospheric Chemistry of Air Pollution. Wiley, New York.

Sobanska, S., Ricq, N., Laboudigue, A., Guillermo, R., Brémard, C., Laureyns, J., Merlin, J.C., Wignacourt, P.J. (1999) Microchemical Investigations of Dust Emitted by a Lead Smelter. Environmental Science and Technology 33, 1334-1339.

Speiser, C., Baumann, T., Niessner, R. (2000) Morphological and Chemical Characterization of CalciumHydrate Phases Formed in Alteration Processes of Deposited Municipal Solid Waste Incinerator Bottom 
Ash. Environmental Science and Technology 34, 50305037.

Sun, Y., Zhuanga, G., Zhanga, W., Wang, Y., Zhuang, Y. (2006) Characteristics and sources of lead pollution after phasing out leaded gasoline in Beijing. Atmospheric Environment 40, 2973-2985.

Tan, M., Zhang, G., Li, X., Zhang, Y., Yue, W., Chen, J., Wang, Y., Li, A., Li, T., Zhang, Y., Shan, Z. (2006) Comprehensive Study of Lead Pollution in Shanghai by Multiple Techniques. Analytical Chemistry 78, 80448050.

Vekemans, B., Janssens, K., Vincze, L., Adams, F., Van Espen, P. (1994) Analysis of X-ray spectra by iterative least squares (AXIL): new developments. X-Ray Spectrometry $23,278-285$.

Wang, J., Guo, P., Li, X., Zhu, J., Reinert, T., Heitmann, J., Spemann, D., Vogt, J., Flagmeyer, R.-H., Butz, T. (2000) Source Identification of Lead Pollution in the Atmosphere of Shanghai City by Analyzing Single Aerosol Particles (SAP). Environmental Science and Technology 34, 1900-1905.

Wang, W., Liu, X.D., Zhao, L.W., Guo, D.F., Tian, X.D., Adams, F. (2006) Effectiveness of leaded petrol phaseout in Tianjin, China based on the aerosol lead concentration and isotope abundance ratio. Science of the Total Environment 364, 175-187.

Wang, X., Sato, T., Xing, B. (2006) Size distribution and anthropogenic sources apportionment of airborne trace metals in Kanazawa, Japan. Chemosphere 65, 2440-
2448.

Widory, D., Liu, X.D., Dong, S.P. (2010) Isotopes as tracers of sources of lead and strontium in aerosols (TSP \& $\mathrm{PM}_{2.5}$ ) in Beijing. Atmospheric Environment 44, 3679-3687.

Winneke, G., Brockhaus, A., Ewers, U., Neuf, M., Kramer, U. (1990) Results from the European multicenter study on lead neurotoxicity in children: implications for risk assessment. Neurotoxicology and Teratology 12, 553559.

Xiao, R., Li, B., Yang, H.X., Zhang, Y.H., Liu, X.D., Liu, F., Li, Y.W. (2008) Source identification and apportionment study on particulate matter and aerosol lead in Beijing. Research of Environmental Sciences (Huanjing Kexue Yanjiu) 21(6), 148-155. (in Chinese with English abstract)

Yule, W., Lansdown, R., Millar, I., Urbanowiez, M. (1981) The Relationship Between Blood Lead Concentration, Intelligence, and Attainment in a School Population: a Pilot Study. Developmental Medicine and Child Neurology 23, 567-576.

Zhang, Y., Wanga, X., Chen, H., Yang, X., Chen, J., Allen, O. (2009) Source apportionment of lead-containing aerosol particles in Shanghai using single particle mass spectrometry. Chemosphere 74, 501-507.

(Received 1 March 2012, revised 29 May 2012, accepted 29 May 2012) 